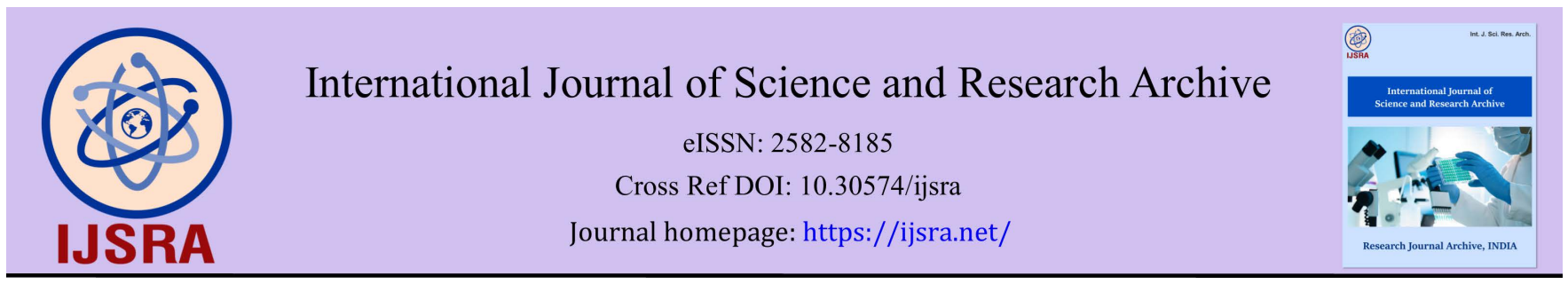

(RESEARCH ARTICLE)

\title{
Chemical analysis of summer honeys collected from Apis dorsata hives of Chandrapur Tahsil of Chandrapur District of Maharashtra State (India)
}

\author{
Laxmikant N Borkar ${ }^{1, *}$ and Devendra M Mate ${ }^{2}$ \\ ${ }^{1}$ Department of Botany, S. S. Jaiswal Arts, Comm. and Science College, Arjuni (Mor), Gondia, India. \\ 2 Department of Botany, Nutan Adarsh Arts, Commerce and M. H. Wegad Science College, Umrer, Dist. - Nagpur.
}

International Journal of Science and Research Archive, 2021, 03(01), 079-081

Publication history: Received on 22 May 2021; revised on 27 July 2021; accepted on 29 July 2021

Article DOI: https://doi.org/10.30574/ijsra.2021.3.1.0078

\begin{abstract}
The present investigation was undertaken to determine the chemical analysis of 5 summer honey samples (CHN-CHNLOH, CHN-CHN-AJA, CHN-CHN-NAN, CHN-CHN-URJ, and CHN-CHN-CHI) collected from forest area of Chandrapur Tahsil of Chandrapur District of Maharashtra State (India). These samples were analyzed for several parameters such as moisture, total reducing sugar, Levulose or Fructose, Dextrose or Glucose, L/D ratio, Sucrose, Acidity. This type of chemical analysis favours the utilization of the honey for good quality in this area.
\end{abstract}

Keywords: Chemical Analysis; Summer Honey; Chandrapur Tahsil

\section{Introduction}

Honey is a carbohydrate rich naturally complex product produced by honey bees from floral nectar. Honey has been used by all civilizations as nutrient food and in traditional medicine. The quality of honey depends on various physiological factors such as climate, soil, etc. Honey contains Sugar, Protein, Moisture, Vitamins, Minerals, Enzymes, Polyphenols and Flavonoids (Al ML - Manary et al., 2002) because of this unique complex nature, honey is proved to be useful in the treatment of burns, wounds, skin ulcers as an antioxidant and iin the treatment of external eye diseases (Balsubramanyam, 2011). Furthermore, honey is a highly valuable ingredient in condiments, beverage, sauces and sweets. In fact numerous studies have been reported on physical, chemical and melissopalynological parameter of honeys from all over the world. (Adenekan et al., 2010; Anklam, 1998; Cherian et al., 2011; Borkar Laxmikant and Mate Devendra, 2014; Downey et al., 2005; Ramnath nad Shivaramm, 2012, Terrab et al., 2002; Xesus et al., 2010). The scientific literature revealed that the information is not available with respect to chemical characteristics of honeys from Chandrapur Tahsil of Chandrapur District of Maharashtra State in India. The purpose of this study has to investigate some chemical prameters such as Moisture, Total Reducing Sugar, Levulose or Fructose, Dextrose or Glucose, Levulose/Dextrose, Sucrose, Acidity and Microscopical analysis of honey collected from different regions of Chandrapur Tahsil of Chandrapur District of Maharashtra State in India.

\section{Material and methods}

Chemical analysis of the honeys are carried out by using Indian Standard Specification, IS: 4941 (1974) and IS: 8464 (1977). The percentage of Total Reducing Sugar, (Levulose or Fructose + Dextrose or Glucose), Levulose, Dextrose, Sucrose, Acidity, Moisture and L/D ratio were estimated.

\footnotetext{
${ }^{*}$ Corresponding author: Laxmikant N Borkar

Department of Botany, S. S. Jaiswal Arts, Comm. and Science College, Arjuni (Mor), Gondia, India.

Copyright (@ 2021 Author(s) retain the copyright of this article. This article is published under the terms of the Creative Commons Attribution Liscense 4.0.
} 


\section{Results and discussion}

The chemical properties of the 5 summer squeezed honey samples (Viz. CHN-CHN-LOH, CHN-CHN-AJA, CHN-CHN-NAN, CHN-CHN-URJ, CHN-CHN-CHI) were collected during the period 16 March, 2012 to 03 May, 2013 from Lohara, Ajaypur, Nandgaon Pole, Urjanagar, Chichpalli respectively from Chandrapur Tahsil of Chandrapur District of Maharashtra State are reported in table.

Table 1 Chemical Analysis of honey samples obtained from Chandrapur Tahsil of Chandrapur District

\begin{tabular}{|c|c|c|c|c|c|c|c|c|c|}
\hline \multicolumn{10}{|c|}{ Parameter } \\
\hline $\begin{array}{l}\text { Sr. } \\
\text { No. }\end{array}$ & $\begin{array}{l}\text { Location of } \\
\text { Parameter }\end{array}$ & $\begin{array}{l}\text { Date of } \\
\text { Collection }\end{array}$ & $\begin{array}{l}\text { Moisture } \\
\%\end{array}$ & $\begin{array}{l}\text { Total } \\
\text { Reducing } \\
\text { Sugar \% }\end{array}$ & $\begin{array}{l}\text { Levulose } \\
\text { or } \\
\text { Fructose } \\
\%\end{array}$ & $\begin{array}{l}\text { Dextrose } \\
\text { or } \\
\text { Glucose } \\
\%\end{array}$ & $\begin{array}{l}\text { L/D } \\
\text { Ratio }\end{array}$ & $\begin{array}{l}\text { Sucrose } \\
\%\end{array}$ & $\begin{array}{l}\text { Acidity } \\
\%\end{array}$ \\
\hline 1 & $\begin{array}{l}\text { CHN-CHN- } \\
\text { LOH }\end{array}$ & $\begin{array}{c}16-03- \\
2012\end{array}$ & 26 & 72.929 & 37.246 & 35.575 & 1.167 & 2.551 & 0.2904 \\
\hline 2 & $\begin{array}{l}\text { CHN-CHN- } \\
\text { AJA }\end{array}$ & $\begin{array}{c}19-03- \\
2013\end{array}$ & 24.5 & 71.098 & 39.584 & 31.514 & 1.398 & 2.010 & 0.4255 \\
\hline 3 & $\begin{array}{l}\text { CHN-CHN- } \\
\text { NAN }\end{array}$ & $\begin{array}{c}10-04- \\
2012\end{array}$ & 23.4 & 65.062 & 35.25 & 29.812 & 1.361 & 1.627 & 0.313 \\
\hline 4 & $\begin{array}{l}\text { CHN-CHN- } \\
\text { URJ }\end{array}$ & $\begin{array}{c}26-04- \\
2013\end{array}$ & 32.43 & 74 & 37.084 & 36.916 & 1.145 & 3.635 & 0.2369 \\
\hline 5 & $\begin{array}{l}\text { CHN-CHN- } \\
\text { CHI }\end{array}$ & $\begin{array}{l}03-05- \\
2013\end{array}$ & 23 & 66.648 & 32.937 & 33.539 & 1.080 & 1.746 & 1.278 \\
\hline
\end{tabular}

In the present study moisture content in the sample ranges from 23-26. Increase in the temperature moisture is low and decrease the temperature moisture is high. Increase in moisture content of honey is also indicative of adulteration. The low moisture content of honey forms an important part of the system which protect honey from attack by microorganism.

\subsection{Sugars}

Honey consists of mostly Glucose and Fructose. The actual proportion of Fructose to Glucose in any particular honey, depends largely on the sources of the nectar. All samples contained more Fructose than Glucose.

This indicated that Chandrapur honeys would be less prone to granulation Fructose level in honey is higher than that of Glucose. Honey with high Fructose to Glucose ratio would remain liquid for longer period. The Fructose/Glucose ratios may have an impact or honey flavor, since fructose is much sweeter than glucose.

\subsection{Acidity}

Acidity of the honey sample ranges by $0.2369-1.278$ respectively. Acidity values may indicative the fermentation of honey sugar by yeast.

\section{Conclusion}

Method enabling the examination of several parameters which would provide the quality of bee honey within a short period of time are needed modern techniques which have been developed and validated over the past few years provide high precision and accuracy but need further improvement so that the natural bee honey available on the market can be tested as quickly and reliably as possible further research into method of honey quality assessment should focus on developing techniques of rapid evaluation of the botanical origin of honey since the principle method currently in use, the melitttopalynological method is very time consuming requires considerable experience botanical knowledge as well as knowledge of the honey production process. It produces inconclusive result which can be difficult to interpret 
meorever it is necessary to devise quick reliable and expensive methods for detecting honey adulteration as an overview of current method of honey quality assessment, this paper can help shape the direction of future research in this field.

\section{Compliance with ethical standards}

\section{Acknowledgments}

The authors are greatful to Mr. Kailash Mohitkar and its Team Chimur Dist Chandrapur for procuring honey sample and his personal interest

\section{Disclosure of conflict of interest}

The author declare no conflict of interest.

\section{References}

[1] Adenekan MO, Amusa NA, Lawal AO, Okpeze VE. Physicochemical and microbiological properties of honey samples obtained from Bada, Journal of Microbiology and Antimicrobials. 2010; 2(8): 100-104.

[2] Al ML, Danial DJ, Moise A, Bebis O, Lasio L, Bogedanov S. Phycochemical and bioachive properties of different floral originhoneys from Romdnia. Food Chemistry. 2002; 112: 863-867.

[3] Anklam EA. A review of the analogical and botanical origine of honey, Food Chemistry. 1998; $63: 549$ - 562.

[4] Balsubramanyam MV. Chemical Characteristics of much floral wild and apiary honeys from Western Ghats of Karnataka. The Bioscan. 2011; 6: 467 - 469.

[5] Borkar Lamikant and Mate Devendra. Chemical Analysis of Summer Honeys collected from Apis dorsata hives of Bhadrawati Tahsil of Chandrapur District of Maharashtra State (India), Int. Res. J. of Sci. \& Engg. 2014; 2(4): 139141.

[6] Cherian KJ, Bhowal M, Godghate SD. Pollen and hysiochemical analysis of honey preduceed by Apis cerena indica of Nagpur, Maharashtra (INDIA). Journal of Environmental Research and Development. 2011; 5(3): 542-550.

[7] Downey GJ, Hussey K, Kelly JD, Walshe TF and Martin PG. Preliminary contribution to the characteristics of artisanal honey produced on the island of Ireland by palynological and physico - chemical data. Food Chemistry. 2005; 91: 347-354.

[8] IS: 4941-1974 Indian Standard Specification for extracted honey (First Revision), Indian Standards Institution, 1974, New Delhi: 1-16.

[9] IS: 8464-1977 Indian Standard Specification for Squeezed honey, Indian Standards Institution, 1977, New Delhi: 1-8.

[10] Ramnath Subharani and Venkataramegouda Sivaramm physicochemical and pollen analysis of Western ghats honey of Karnataka south, India. I.J. S.N. 2012; 3(4): 831- 835.

[11] Terrab AJ, Diez MJ and Heredia FJ. Characterization of Moroccan unifloral honeys by theis physicochemical characteristics. Food Chemistry. 2002; 79: 373 - 379.

[12] Xesus FJ, Jose P, Maria LE, Antonio I and Jose PA. Palynological and physicochemical data charctrazation of honeys produced in the Entre - Douro e Munho region of Portugal, International Journal of food Science and Technology. 2010; 45: 1255-1262. 